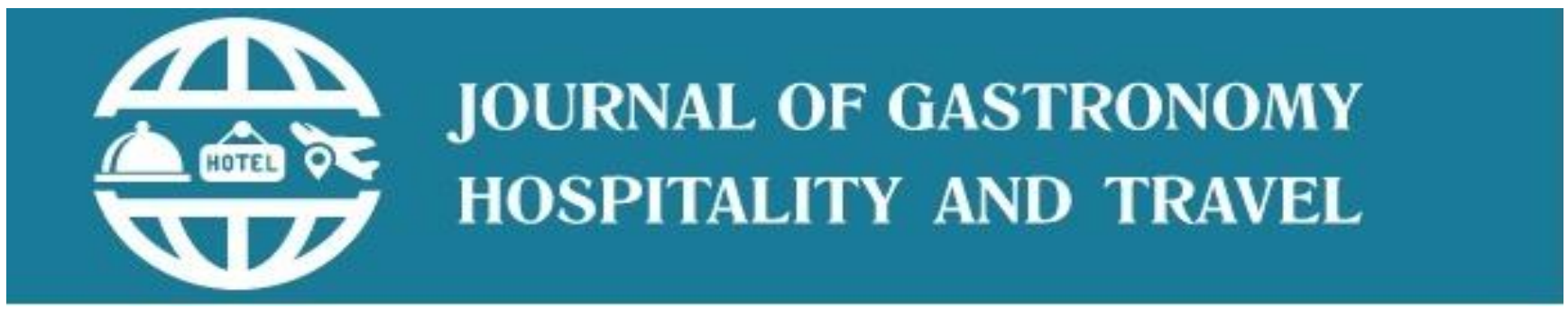

ISSN: $2619-9548$

Journal homepage: www.joghat.org, http://dergipark.gov.tr/joghat

Journal of Gastronomy, Hospitality and Travel (JOGHAT)

2019 - Volume: 2 Number: 2

Page: 87-107

Received: 21.11 .2019

Revised: 01.12 .2019

Accepted: 05.12.2019

\title{
Research Article \\ INVESTIGATION OF THE IMPLEMENTATION OF INTERNAL MARKETING TO HOTELS: THE CASE OF HOTELS OF THE CHANIA PREFECTURE, GREECE
}

\author{
Georgia ZOUNI ${ }^{*}$ (orcid.org/0000-0002-3388-1591) \\ Evangelia BOGRI*** ${ }^{*}$ (orcid.org/0000-0001-7684-2886) \\ Ioanna GEORGAKI*** (orcid.org/0000-0002-8966-7690)
}

*Adjunct Lecturer of Tourism Marketing, University of Piraeus, Department of Business Administration, Athens, Greece, email:
gzouni@ gmail.com
${ }^{* *}$ MSc in Tourism Business Administration, Hellenic Open University, Greece, e-mail: evi1302@ gmail.com
${ }^{* * *}$ MSc in International Business Management with Tourism, Heriot-Watt University, e-mail: ioannag33@ hotmail.com

\begin{abstract}
The hotel industry is directly associated with marketing in general, both the external and the internal one. Hotels are companies that provide services which means that the workforce of the company gets in direct (personal) touch with its customers. However, the implementation of internal marketing is not only proven indispensable for companies that provide services, but it can also apply to other types of companies, such as the industrial sector. The aim of the paper is twofold: (a) Measurement of the implementation of internal marketing as well as measurement of job satisfaction at the hotels of a particular area, and (b) Investigation of the awareness of directors-remaining administrative personnel and subordinates-employees on issues of internal marketing and job satisfaction. Results demonstrate low percentages of the implementation of internal marketing in hotels in the majority of aspects of internal marketing.
\end{abstract}

Keywords: Internal Marketing, Service Marketing, Hotels, Satisfaction, Awareness

\footnotetext{
${ }^{1}$ To cite this document: Zouni, G., Bogri, E. and Georgaki, I. (2019). Investigation of the Implementation of Internal Marketing to Hotels: The Case of Hotels of the Chania Prefecture Greece, Journal of Gastronomy Hospitality and Travel, 2(2), 87-107. DOI: 10.33083/joghat.2019.18
}

Corresponding author: gzouni@gmail.com 